\title{
O nazivu učinska / energetska elektronika
}

\author{
Zvonko Benčić \\ Fakultet elektrotehnike i računarstva Sveučilišta u Zagrebu \\ zvonko.bencic@fer.hr
}

SAŽETAK: U radu je istražena uporaba imenica učin i pridjeva učinski u hrvatskom elektrotehničkom nazivlju, od objave Šulekova Hrvatsko-njemačko-talijanskoga rječnika znanstvenoga nazivlja 1874. godine do danas. Utvrđeno je da naziv energetska elektronika obuhvaća samo dio učinske elektronike, i to onaj koji se koristi u elektroenergetici. Naziv učinska elektronika u skladu je s nazivima u većini europskih jezika, npr. s nazivima na engleskom, njemačkom, francuskom, ruskom, talijanskom i slovenskom jeziku te zadovoljava sva terminološka načela.

Ključne riječi: energetska elektronika; učinska elektronika; učin; učinak

\section{Uvod}

Posljednjih se nekoliko godina među inženjerima elektrotehnike raspravlja se o tome kako treba vratiti skupini predmeta iz učinske elektronike stariji naziv energetska ${ }^{1}$ elektronika. Dva su argumenta za to: prvo, naziv učin nije općenito prihvaćen u elektrotehničkom nazivlju i drugo, oni koji su studirali od 1960. do 1990. priviknuli su se na naziv energetska elektronika.

Osnovna je svrha i cilj ovoga rada utvrditi značenje pridjeva učinski u nazivu učinska elektronika te opravdati uporabu imenice učin u hrvatskom elektrotehničkom nazivlju. U tu svrhu popisane su riječi učinski i učin u rječničkoj, stručnoj i udžbeničkoj literaturi.

1 Od imenice energetika pravilno izveden je pridjev energetički, od imenice energija pravilno izveden pridjev je energijski. Pridjev energetski odnosi se na energetiku (HJP 2020). Nastao je posuđivanjem u hrvatski jezik i nije u skladu s terminološkim savjetom koji glasi da ako već posuđujemo imenicu iz stranoga jezika ne trebamo posuđivati i pridjev nego se on izvodi iz posuđene imenice. No pridjev energetički u inženjerskoj zajednici nije prihvaćen. 


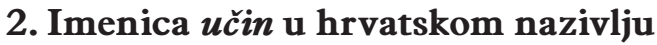

Hrvatsko-njemačko-talijanski rječnik znanstvenog nazivlja (Šulek 1874)

Uěilo, phil. \&ehrmittel.

Uěin, hist. Factum, TGatfadye, tal. fatto; phil. volfendete That, tal. fatto.

Uěiniti, stil. (poč in iti), thun, tal. fare; učiniti zločin, ein Berbreduen begehen, tal. commettere un delitto; učiniti, phil. (izvesti), berwirfen, tal. effettuare, eseguire; merc. u čin iti pogodbu ili ugovor, einen Bertrag abjoliejen, tal. conchiudere un accordo 9 contratto, far contratto; učinitil

Slika 1. Preslika natuknice učin (Šulek 1874: 1206)

Imenicu učin Šulek je uvrstio u svoj terminološki rječnik (slika 1). Transliteriran tekst glasi:

Učin, hist. Factum², Thatsache, tal. fatto;

phil. vollendete That, tal. fatto.

U Šulekovu rječniku rabljene riječi objašnjene su ovako:

Factum, stil. Thatsache, učin; njem. Begebenheit, dogodjaj; math. Factum, Product, umnožak

Thatsache, stat. phil. učin, frc. fait accompli; vollbrachte Th., svršen posao

Fatto, hist. (atto), dogodjaj, učin (azione), djelo, čin; (faccenda), posao

Njemačka sintagma: vollendete That, učin, ostvareno djelo. Kratice označuju (prema Tumaču skraticah u Šulekovu rječniku): frc. franczki, hist. historia, mat. mathesis oder mathematica, phil. philosophia, stil. stilistica, tal. talijanski.

\footnotetext{
2 Riječi napisane Yu Gothic UI Semilight fontom u Šulekovu su rječniku pisane goticom.
} 
Rječnik hrvatskoga ili srpskoga jezika (Musulin, Pavešić 1967-71: 151-152)

Prepisani su samo dijelovi natuknice koji su relevantni za ovaj članak:

1. UČIN, učcin, $m$.

c) ono, što je učineno, djelo, učinak, čin, činenica, događaj, rezultat, posledica.

2. UČIN, f. djelo, postupak

Opaska: U rječnike hrvatskoga/hrvatskoga ili srpskoga jezika (Šonje 2000; Šarić, Wittschen 2008; Anić 2002; HJP 2020) nije uvrštena imenica učin!

\section{Pravopisi i pravopisni priručnici}

Tablica 1. Imenica učin u pravopisnim rječnicima

\begin{tabular}{|c|c|}
\hline Publikacija & Pravopisni rječnik \\
\hline $\begin{array}{l}\text { Pravopis hrvatskoga ili srpskoga jezika (Boranić } \\
\text { 1941, 1951) }\end{array}$ & učin, $\operatorname{čin}^{(1)}$ \\
\hline $\begin{array}{l}\text { Pravopis hrvatskosrpskog jezika (Jonke-Stevanović } \\
\text { 1960, 1967) }\end{array}$ & nije u pravopisnom rječniku \\
\hline $\begin{array}{l}\text { Hrvatski pravopis (Babić, Finka, Moguš 1971, } \\
\text { 1996) }\end{array}$ & učin $(\text { čin, učinak })^{(2)}$ \\
\hline $\begin{array}{l}\text { Pravopisni priručnik hrvatskoga ili srpskoga jezika } \\
\text { (Anić, Silić 1987) }\end{array}$ & nije u pravopisnom rječniku \\
\hline Hrvatski jezični portal (HJP 2020) & nije u rječničkoj bazi \\
\hline
\end{tabular}

\section{Imenica učin u hrvatskom elektrotehničkom nazivlju}

Skripta faka struja I (Plohl 1927a: 17)

U VI. svesku, u definiciji djelotvornosti (stupnja djelovanja) generatora, Plohl rabi sintagmu korisni učin.

Skripta faka struja II (Plohl 1927b, 1928b)

Plohl djelotvornost transformatora definira omjerom (sekundarni korisni efekt)/(primarni uvedeni efekt) (Plohl 1928b). Također spominje efekt trofazne struje (Plohl 
1928a). Lončar umjesto imenice efekt (rezultat djelovanja struje) upotrebljava istoznačnicu učin, a imenicu efekt stavlja u zagradu (Lončar 1942).

\section{Udžbenik Osnovi elektrotehnike I (Lončar 1942)}

U poglavlju IV. »Radnja i učin struje. Strujna toplina« Lončar na nekoliko mjesta rabi riječ učin.

a) »Kako je množina elektriciteta $[Q]^{3}$ prenesena vremenski konstantnom strujom $I \mathrm{u}$ vremenu $t$ jednaka $Q=I t$, za radnju električne struje, može se postaviti formula: $A=U I t$ [ $U$ je napon potreban za tok struje], a za učin (snagu, efekt), t. j. radnju u jedinici vremena, formula $N=U I_{\ll}$ (str. 155).

b) »Tako se u elektronskoj cijevi s dvije elektrode [diodi] iz sl. 63 na str. 118 učin $U_{\mathrm{a}} I_{\mathrm{a}}$ troši na ubrzavanje, odn. stvaranje kinetičke energije elektrona na njihovom putu između katode $\mathrm{K}$ i anode $\mathrm{A}$, ...« (str. 156).

c) Kod razmatranja učinkovitosti električnih žarulja uvodi pojam potrǒseni električni učin ili kraće potrošak učina (str. 164). Naime, samo manji dio potrošenoga električnoga učina pretvara se u svjetlost (elektromagnetsko zračenje koje je vidljivo ljudskim okom) (str. 159).

d) Ako treba razlikovati učine različite fizikalne prirode, dodaje pridjev, npr. ukupni svjetlosni učin, električki učin (str. 162) i sl.

e) Rabi i sintagme (str. 168): gubitak učina (npr. kod punjenja akumulatora), prenos učina (kod dalekovoda) i ukupni učin (npr. strujnoga kruga).

U naslovu poglavlja IV. jesu imenice radnja i učin. Iz teksta je očito da im Lončar pridaje fizikalno različita značenja.

\section{Udžbenik Osnovi elektrotehnike II (Lončar 1947)}

U poglavlju G. »Strojevi izmjenične struje« (Asinhroni indukcioni motori) Lončar upotrebljava imenicu učin u dvije sintagme:

»Od prenesenih na sekundarni dio svakih $10000 \mathrm{~W}$ otpao bi onda $0,04 \cdot 10000=400 \mathrm{~W}$ na gubitke u bakru rotora, a $9600 \mathrm{~W}$ dalo bi 'proizvedeni mehanički učin', i po tom bi, uz pretpostavku $100 \mathrm{~W}$ gubitaka zbog trenja i sl. 'korisni mehanički učin' bio $9500 \mathrm{~W} . \lll$

\footnotetext{
3 U uglatim zagradama dodana su objašnjenja potrebna za razumijevanje teksta.
} 
Dabac (1969) u svojem njemačko-hrvatskosrpskom rječniku proizvedeni/korisni mehanički učin naziva učinak.

\section{Udžbenik Osnovi elektrotehnike I (Lončar 1956)}

Ovo četvrto prošireno izdanje udžbenika rezultat je svih prethodnih izdanja, odnosno možemo ga smatrati »završnim mišljenjem« akademika Lončara.

Naslov IV. poglavlja koji je u izdanju iz 1942. glasio »Radnja i učin struje. Strujna toplina« jest proširen i u izdanju iz 1956. glasi »Rad (radnja) i snaga (učin) struje; strujna toplina« (str. 166). Očito je da je radnja sinonim za rad, a učin za snagu. Sam je tekst ostao isti: isključivo se rabe riječi radnja i učin.

\section{Udžbenik Osnovi elektrotehnike II (Lončar 1958)}

Glede naziva učin karakterističan je odsječak na str. 17:

»Kako se vidi, u izrazu (255) $[N=E \cdot I \cos \varphi]$ za pravi ili radni učin $\mathrm{u}$ W dolaze efektivne vrijednosti $E$ i $I$... Faktor $k=\cos \varphi$ zove se faktor učina (faktor snage), a za razliku od pravog učina $N \mathrm{u}$ W produkt $E I$ dobio je ime prividni učin $N$ u VA. S razloga koje ćemo doskora upoznati javlja se katkad u razmatranjima također i prazni (jalovi) učin: $N^{\prime}=E I \cdot \sin \varphi=$ $N^{\prime \prime} \cdot \sin \varphi$....

U poglavlju »II) Polifazni sustavi izmjeničnih struja« mogu se naći sintagme:

- učin polifaznih sustava (str. 65)

- ukupni učin svih faza (str. 65)

- srednji učin trofaznog sustava (str. 66)

- mjerenje učina (str. 66)

- primarni faktor učina (str. 174)

- faktor učina mreže (str. 215)

- mehanički učin (str. 229)

- gubitak učina (str. 282) i sl. 


\section{Udžbenik Električka mjerenja (Lončar 1965)}

Prvo izdanje tog udžbenika objavljeno je 1939. godine. Ovo četvrto izdanje razlikuje se od prvoga samo u tome što je dodan na kraju udžbenika dodatak (51 stranica). U udžbeniku pojavljuju se sintagme kojih nema u udžbenicima (Lončar 1956) i (Lončar 1958):

- učin generatora (str. 115), potrošača (str. 115), sijalice (str. 117)

- istosmjerni učin (str. 201)

- izmjenični učin (str. 201)

- faktor praznoga učina (str. 204)

- faktor prividnoga učina (str. 204)

Tehnički rječnik - njemačko-hrvatskosrpski (Dabac 1969)

Popisane su samo njemačke riječi u čijem je hrvatskom prijevodu riječ učin. To su:

Leistung [specifische Produktion] učin [specifična proizvodnja, npr. $\mathrm{t} / \mathrm{h}, \mathrm{m}^{3} / \mathrm{d}$, komada/h]

Leistung, ausgebaute izgrađena snaga, izgrađeni učin

Leistung einer pumpe učin pumpe

Leistung, normale normalna snaga, normalni učin

Leistungsabnahme odvedena snaga, smanjenje snage (učina)

Leistungsbegrenzungsschutz granična učinska zaštita [nadučinska odn. podučinska zaštita]

Leistungsfähighkeit učinak, učin, proizvodnost, radna sposobnost, moć, izdržljivost

Leistungsfähighkeit radna ili proizvodna sposobnost,

[z.B. eines Schalters, Maschine usw.]

Leistungsrückgang [Filter] proizvodnost, moć, valjanost [npr. sklopke, stroja itd.] opadanje učina, smanjenje učina 
Tehnički rječnik - hrvatskosrpsko-njemački (Dabac 1970)

Treba uočiti široku uporabu imenice učin izvan područja elektrotehnike, slika 2. Hrvatske riječi / sintagme koje sadrže riječ učin, koje se upotrebljavaju ili se mogu upotrijebiti u elektrotehnici su:

$\begin{array}{ll}\text { učin [npr. m³/h; kom/d; t/min] } & \begin{array}{l}\text { Leistung, Lieferfähighkeit, Wirkung, } \\ \text { Effekt, Leistungsfähighkeit }\end{array} \\ \text { učin [propusna sposobnost] } & \text { Durchsatz, Durchsatzleistung } \\ \text { učin [učinak] } & \text { v. učinak, učin } \\ \text { učin, godišnji } & \text { Fahresleistung } \\ \text { učin, granični } & \text { Grenzleistung } \\ \text { učin, izgrađeni } & \text { ausgebaute Leistung } \\ \text { učin, jedinični } & \text { Einheitleistung } \\ \text { učin, korisni [npr. Ah, Wh] } & \text { Nutzleistung } \\ \text { učin (lampe), svjetlosni } & \text { Lichtleistung (der Lampe) } \\ \text { učin, maksimalni } & \text { Höchstleistung, Maximalleistung } \\ \text { učin, nazivni } & \text { Nennleistung } \\ \text { učin, normalni } & \text { normale Leistung, Normaleistung } \\ \text { učin, pogonski } & \text { Betriebsleistung } \\ \text { učin, pojedinačni } & \text { Einzelleistung } \\ \text { učin, prosječni } & \text { Durchschnitleistung } \\ \text { učin, satni [npr. m } / \mathrm{h}] & \text { Stundenleistung } \\ \text { učin, srednji } & \text { Mittelleistung } \\ \text { učin, trajni } & \text { Dauerleistung } \\ \text { učin, ukupni } & \text { Gesamtleistung } \\ \text { učin, vršni ili maksimalni } & \text { Spitzenleistung }\end{array}$


Studia Iexicographica, 14(2020) 26, STR. 147-171

Zvonko Benčić: O nazivu učinska / energetska elektronika

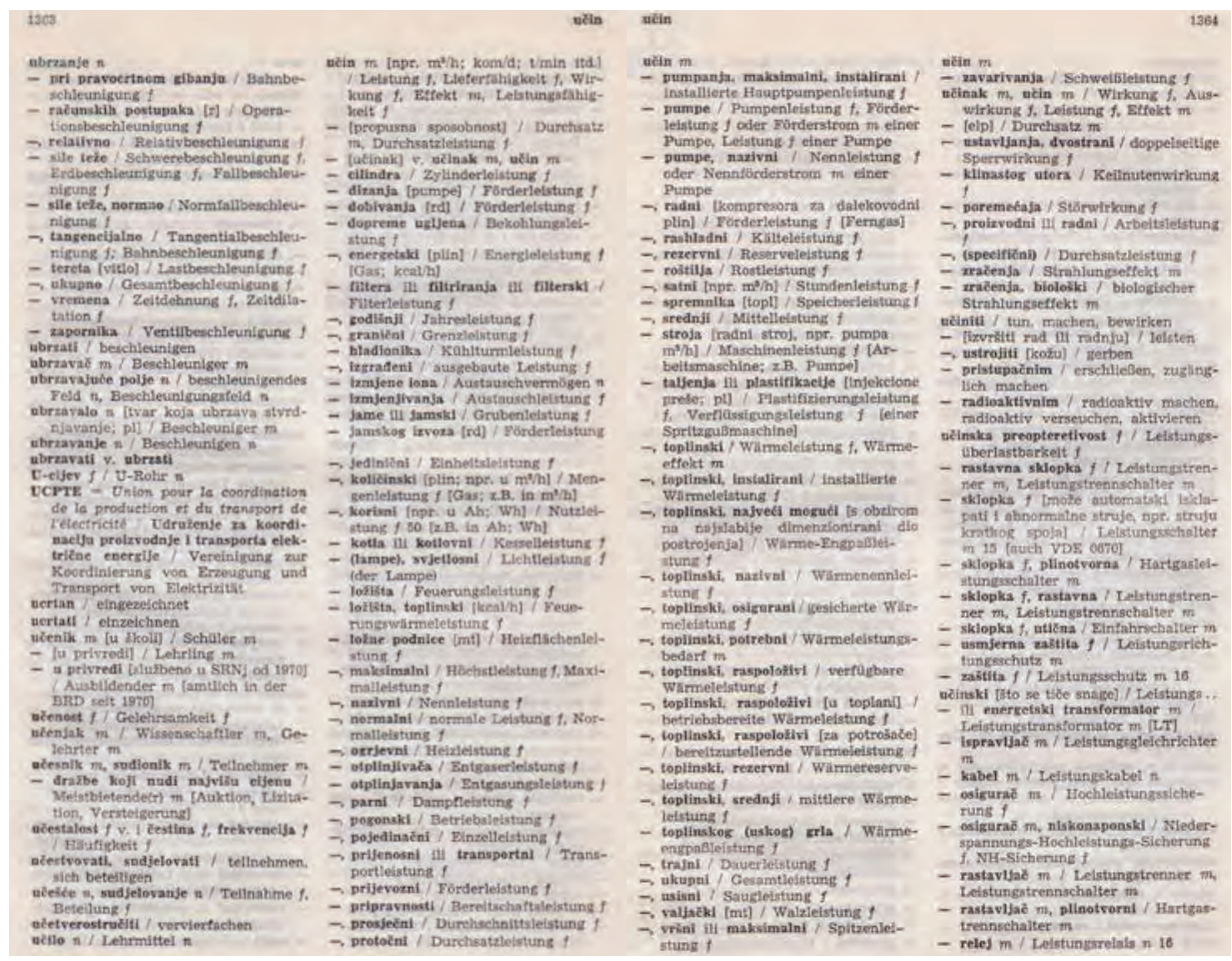

Slika 2. Izvan područja elektrotehnike česta je imenica učin (Dabac 1970: 1363-1365)

Elektrotehnički rječnik - njemačko-hrvatski(Muljević 1996)

Leistung

Leistungsprüfung

Leistungsfähighkeit snaga, učin, učinak, djelovanje; usluga

ispitivanje snage / učina

učinak, učin, radna sposobnost, moć, izdržljivost

Elektrotehnički rječnik - hrvatsko-njemački (Muljević, Horvatić 2000)

učin, usp. učinak

učin, energetski

učin, influencije

učin, izgradnje

učin, jedinični
Leistung, Leistungsfähigkeit

Energieleistung

Influenzeffect

Ausbauleistung

Einheitsleistung 


$\begin{array}{ll}\text { učin, količinski } & \text { Mengeleistung } \\ \text { učin, korisni izlazni } & \text { Nutzausgangleistung } \\ \text { učin, kotla } & \text { Kesselleistung } \\ \text { učin nabijanja kapaciteta } & \text { Kapacitätsleistung } \\ \text { učin, najveći } & \text { Höchleistung, Maximalleistung } \\ \text { učin, obroka / doze energije } & \text { Energiedosisleistung } \\ \text { učin, ogrjevni } & \text { Heizleistung } \\ \text { učin, pojedinačni } & \text { Einzelleistung } \\ \text { učin, prijevozni } & \text { Förderleistung } \\ \text { učin pripravnosti } & \text { Bereitschaftleistung } \\ \text { učin, prosječni } & \text { Durchschnittsleistung } \\ \text { učin, radni } & \text { Förderleistung } \\ \text { učin, rashladni } & \text { Kälteleistung } \\ \text { učin, sisalike / pumpe } & \text { Pumpenleistung } \\ \text { učin, sisaljke / pumpe, nazivni } & \text { Nennförderstrom der Pumpe } \\ \text { učin, spremnika (topline) } & \text { Speicherleistung } \\ \text { učin, stroja } & \text { Maschinenleistung } \\ \text { učin, svjetlosni } & \text { Lichtleistung } \\ \text { učin telegrafiranja } & \text { Telegrapfieleistung } \\ \text { učin, toplinski } & \text { Wärmeleistung, Wärmeeffect } \\ \text { učin, trajni } & \text { Dauerleistung } \\ \text { učin, usisivanja } & \text { Saugleistung } \\ \text { učin, usisni } & \text { Saugleistung } \\ \text { učin, visoki } & \text { Hochleistung } \\ \text { učin zavarivanja } & \text { Schweissleistung } \\ \text { učin zvuka } & \text { Schalleistung } \\ & \end{array}$

Zaključno, u elektrotehničkom su nazivlju učin, snaga i efekt istoznačnice. Imenica učinak ima tri značenja: (1) učin, (2) posljedica učina i (3) korisni dio učina. 


\section{Pridjev učinski u hrvatskom elektrotehničkom nazivlju}

\section{Oglas u časopisu Informacije Rade Končar (Belin 1954)}

U oglasu, pridjev učinski nalazi se u dvije sintagme: učinski transformatori i učinske sklopke. Iz oglasa je očito da se radi o transformatorima i sklopkama koji se koriste u elektroenergetici.

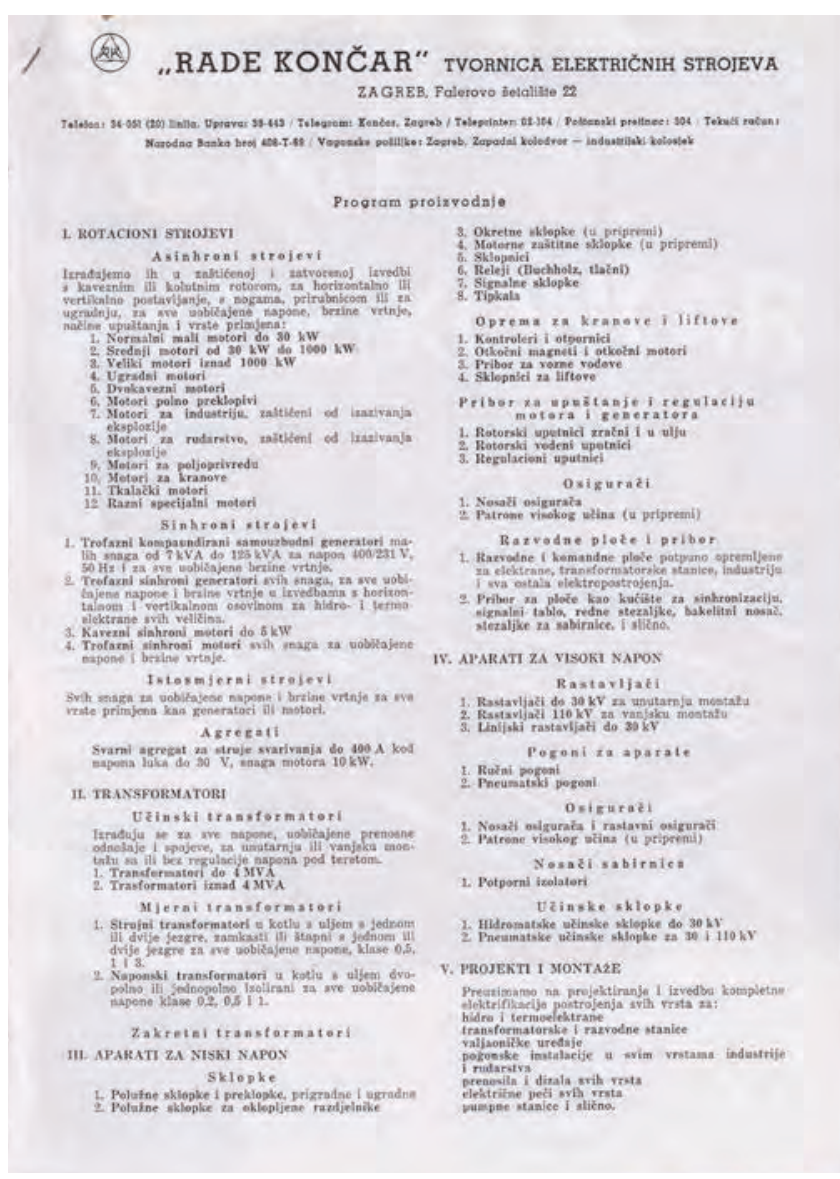

Slika 3. Godine 1954. u Poduzeću »Rade Končar« upotrebljavao se pridjev učinski (Belin 1954)

\section{Oglas u udžbeniku Elektrotehnika - osnovi (Kaiser 1956) [29]}

Ovaj oglas proširenje je oglasa u časopisu Informacije Rade Končar s nekoliko novih podataka; no ponavljaju se nazivi učinski transformatori i učinske sklopke. 

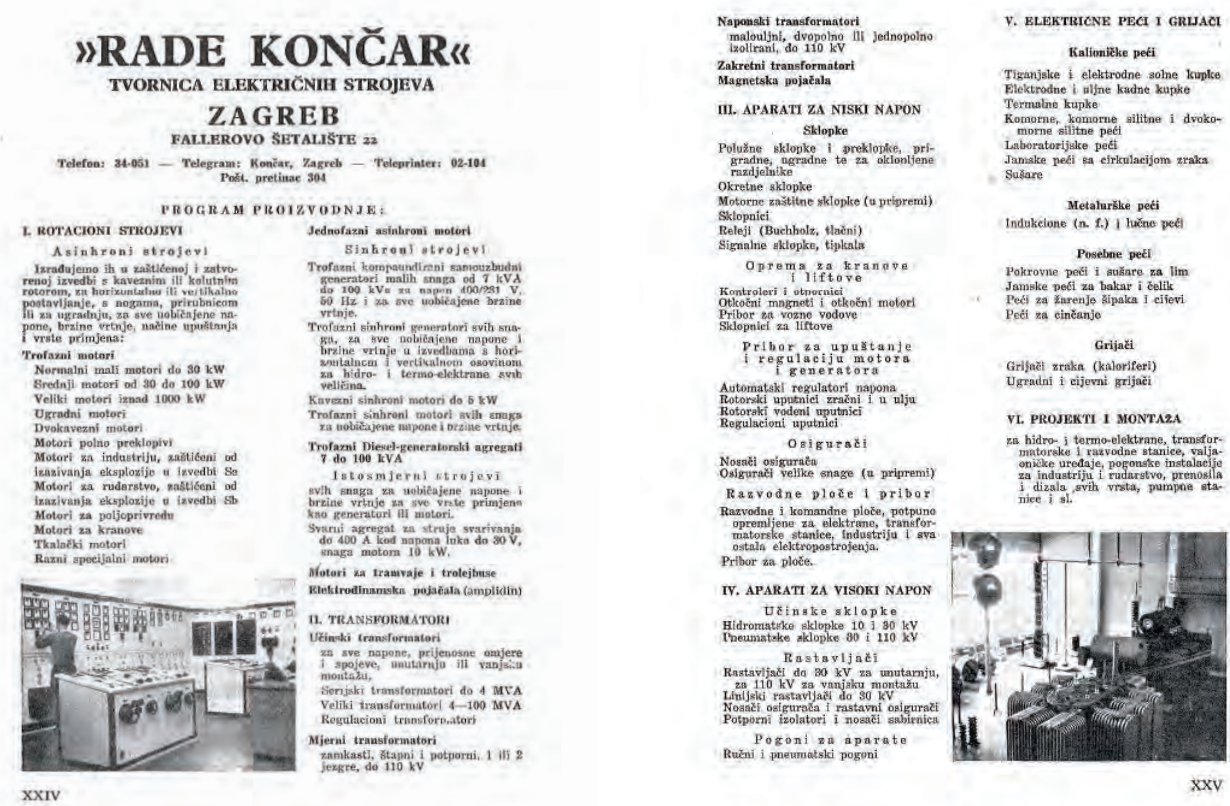

Slika 4. Oglas Poduzeća »Rade Končar« u udžbeniku Elektrotehnika - osnovi

(Kaiser 1956: XXIV-XXV)

Udžbenik Osnovi elektrotehnike II (Lončar 1958: 322)

- učinsko pojačanje

Tehnički rječnik - njemačko-hrvatskosrpski (Dabac 1969)

Leistungsbegrenzungsschutz

Leistungsgleichrichter

Leistungsrelais

Leistungsrichtungsrelais

Leistungsrichtungsschutz

Leistungsschalter granična učinska snaga

[nadučinska odn. podučinska zaštita]

učinski ispravljač

učinski relej

usmjereni učinski relej

učinska usmjerna zaštita

učinska sklopka 
Leistungsschutz

Leistungstransformator

Leistungstransistor

Leistungstrenner

Leistungstrennschalter učinska zaštita

učinski ili energetski transformator

učinski tranzistor

učinski rastavljač

rastavna učinska sklopka

Tehnički rječnik - hrvatskosrpsko-njemački (Dabac 1970)

učinska preopteretivost

učinska rastavna sklopka

učinska sklopka

učinska sklopka, plinotvorna

učinska sklopka, rastavna

učinska sklopka, utična

učinska usmjerna zaštita

učinska zaštita

učinski ili energetski transformator

učinski ispravljač

učinski kabel

učinski osigurač

učinski rastavljač

učinski rastavljač, plinotvorni

učinski relej

učinski relej s određenim kutom

učinski relej, usmjereni

učinski tranzistor
Leistungsüberlastbarkeit

Leistungstrenner, Leistungstrennschalter

Leistungsschalter

Hartgasleistungsschalter

Leistungstrenner, Leistungstrennschalter

Einfahrschalter

Leistungsrichtungsschutz

Leistungsschutz

Leistungstransformator

Leistungsgleichrichter

Leistungskabel

Hochleistungssicherung

Leistungstrenner, Leistungstrennschalter

Hartgastrennschalter

Leistungsrelais

Mischleistungsrelais

Leistungsrichtungsrelais

Leistungstransistor, Endtransistor 
Elektrotehnički rječnik - njemačko-hrvatski (Muljević 1996)

Leistung

Leistungsdiode

Leistungsfähigkeit

Leiustungsfernselbst-schalter

Leistungsferrit

Leistungsfilter

Leistungsflussdiagramm

Leistungsgebiet

Leistungsgrenzschalter

Leistungsimpulstransformator

Leistungsinanspruchnahme

Leistungskabel

Leistungskapazität

Leistungskennzahl

Leistungsklystron

Leistungskontakt

Leistungskreis

Leistunglinie

Leistungsmesssender

Leistungsölschütz

Leistungsölströmungsschalter

Leistungsoszillator

Leistungspentode

Leistungsquotient snaga, učin, učinak, djelovanje; usluga

učinska dioda

učinak, učin, radna sposobnost, moć, izdržljivost

daljinska automatska učinska sklopka

učinski ferit

učinski filtar

učinski dijagram toka

učinsko područje

granična učinska sklopka

učinski impulsni transformator

učinska zauzetost, učinsko opterećenje

energetski / učinski kabel

učinski kapacitet

učinski koeficijent

učinski klistron, klistron snage

učinski kontakt

učinski strujni krug

učinska krivulja

učinski generator signala)

učinski uljni sklopnik / kontaktor

učinska malouljna sklopka

učinski oscilator

učinska / izlazna pentoda

učinski kvocijent 
Leistungsreihe

Leistungsrelais

Leistungsrichtungsrelais

Leistungsrichtungsschutz

Leistungsröhre

Leistungsrückgang

Leistungsschaltelement red snage, učinski red

učinski relej

usmjereni učinski relej

učinska usmjerna zaštita

učinska / snažna / izlazna

elektronka

opadanje / smanjenje učina

učinski rasklopni element)

Elektrotehnički rječnik - hrvatsko-njemački (Muljević, Horvatić 2000)

učinska automatska sklopka

učinska dioda

učinska elektronika

učinska elektronka

učinska elektronka s putujućim/

/progresivnim valom

učinska elektrotehnika

učinska konverzija

učinska krivulja

učinska malouljna sklopka

učinska pentoda

učinska preopteretivost

učinska regulacijska sklopka

učinska sklopka

učinska sklopka predstupnja

učinska sklopka, daljinska

automatska

učinska struja
Leistungsselbstschalter

Leistungsdiode

Leistungselektronik

Leistungsröhre

Leistungswanderfeldröhre

Leistungselektrik

Leistungswechselrichtung

Leistunglinie

Leistungsölströmungsschalter

Leistungspentode

Leistungsüberlastbarkait

Lastregelschalter

Kraftschalter, Krafteinschalter,

Leistungsschalter

Vorstufenleistungsschalter

Leistungsfernselbstschalter

Leistungsstrom 


$\begin{array}{ll}\text { učinska tarifa } & \text { Leistungstarif } \\ \text { učinska trioda } & \text { Leistungstriode } \\ \text { učinska usmjerna zaštita } & \text { Leistungsrichtungsschutz } \\ \text { učinska utična naprava } & \text { Kraftsteckvorrichtung } \\ \text { učinska utičnica } & \text { Kraftsteckdose } \\ \text { učinska zaštita } & \text { Leistungsschutz } \\ \text { učinska zauzetost } & \text { Leistungsinanspruchnahme } \\ \text { učinska Zenerova dioda } & \text { Leistungszenerdiode } \\ \text { učinski dijagram toka } & \text { Leistungsflußdiagramm } \\ \text { učinski ferit } & \text { Leistungsferrit } \\ \text { učinski filtar } & \text { Leistungsfilter } \\ \text { učinski generator signala } & \text { Leistungsmeßsender } \\ \text { učinski impulsni transformator } & \text { Leistungsimpulstransformator } \\ \text { učinski ispravljač } & \text { Leistungsgleichrichter } \\ \text { učinski izmjenjivač } & \text { Leistungswechselrichter } \\ \text { učinski kabel } & \text { Leistungskabel } \\ \text { učinski kapacitet } & \text { Leistungskapacität } \\ \text { učinski klistron } & \text { Leistungsklystron } \\ \text { učinski koeficijent } & \text { Leistungskennzahl } \\ \text { učinski kontakt } & \text { Leistungskontakt } \\ \text { učinski kvocjent } & \text { Leistungsquotient } \\ \text { učinski MOS tranzistor } & \text { MOS-Leistungstransistor } \\ \text { učinski napon } & \text { Leistungsspannung } \\ \text { učinski odašiljač } & \text { Leistungssender } \\ \text { učinski oscilator } & \text { Leistungsoszillator, } \\ \text { učinski otpornik } & \text { Power-Oscillator(engl.), } \\ \text { Leistungsfähiger Oszillator } \\ \text { Leistungswiderstand }\end{array}$


učinski postavnik

učinski rasklopni element

učinski rasklopni stupanj

učinski rastavljač

učinski red

učinski relej

učinski relej s određenim

(faznim) kutom

učinski sklopnik / kontaktor

učinski strujni krug

učinski svitak

učinski transformator

učinski tranzistor

učinski uklopni tranzistor

učinski uljni sklopnik / kontaktor

učinski usmjerivač

\section{Leistungssteller}

Leistungsschaltelement

Leistungsschaltstuffe

Lasttrennschalter

Leistungsreihe

Leistungsrelais

Mischleistungsrelais

Leistungsschütz

Leistungskreis

Leistungsspule

Leistungsumspanner

Leistungstransformator

Endtransistor, Leistungstransistor

Leistungsschalttransistor

Leistungsölschütz

Leistungsstromrichter

Elektrostrojarski rječnik - englesko-hrvatski i hrvatsko-engleski (Vrban 2003)

učinska sklopka, prekidač

učinski kabel

circuit breaker

power cable circuit breaker

power cable

prekidač, učinska sklopka

energetski kabel, učinski kabel

Sintagme koje izrazito pripadaju učinskoj elektronici u navedenim rječnicima jesu npr. učinska dioda, učinska konverzija, učinska sklopka, učinski filtar, učinski ispravljač, učinski izmjenjivač, učinski MOS tranzistor, učinski usmjerivač. 


\section{Značenje nekih riječi korijena učin}

U prirodnim i tehničkim znanostima, posebice u fizici i elektrotehnici, značenje riječi može se u mnogim slučajevima »otkriti« odgovorom na pitanje kojom se mjernom jedinicom mjeri pojava koju označuje određena riječ. Primjerice, snaga se mjeri jedinicom Ws/s ili kraće Ws, tj. brzinom kojom se prenosi energija ili obavlja rad (Lopac 2009: 214).

Tako se učin mjeri obavljenim radom (Ws) u jedinici vremena (s), dakle u vatima (W). Učin je kauzalno izazvan (prouzročen) tokom struje; za tok struje potreban je napon. Učinak je dio učina koji se u nekoj komponenti/uređaju pretvara u koristan rad, primjerice u motoru mehanički rad; mjeri se naravno u vatima (W). Učinkovitost je omjer izlazne korisne veličine i ulaznoga uloženog učina, primjerice kod žarulje omjer izlaznoga svjetlosnog toka i ulaznoga električnog učina; mjeri se u lumenima po vatu $(\mathrm{lm} / \mathrm{W})$. Učinkovitost se u tehničkoj praksi često naziva djelotvornošću ili stupnjem djelovanja (Jakobović 2007).

Evo kratkih definicija glede primjene u elektrotehnici:

učin $m$ [G -ka, $\mathbf{N} m n$-ini, G -ina]; rad u jedinici vremena

učinski ( $\check{z}-\mathrm{a}, s-\mathrm{o})$ prid. [G -oga, -og]; koji se odnosi na učin

učinak $m$ [G -inka, N $m n$-inci, G -aka]; rezultat rada, proizvod, posljedica nečega, ono što postoji po drugome kao rezultat neke radnje (HJP); UČINAK, učinka, m. djelo, djelovańe, uspjeh, učin, posljedica (Musulin, Pavešić 1967-71: 152)

učinkovit $(\check{z}-\mathrm{a}, s-\mathrm{o})$ prid. [G -a, odr. učinkoviti, G -oga, -og]; koji donosi plod ili rezultat, djelotvoran (Šonje 2000)

učinkovito pril.; na učinkovit način (HJP)

učinkovitost $\check{z}$ (G -osti | -osti/-ošću); svojstvo onoga što je učinkovito, djelotvornost, stupanj djelovanja (HJP)

Ono što izaziva događaj zove se uzrok. Tako je struja uzrok učina, a učin uzrok učinka (npr. mehaničkog, toplinskog i sl.) (Kutleša 2019). Zgodno je reći: učin električne struje stvara mehaničke, toplinske, svjetlosne ... učinke. 


\section{Naziv učinska elektronika u hrvatskom elektrotehničkom nazivlju}

\section{Rade Končar - Tehnički priručnik (Jurjević, Plavec 1980)}

U tom priručniku nema riječi učin. Naziv učinski transformatori zamijenjen je nazivom energetski transformatori. Zamjena je potpuno ispravna jer se u priručniku radi o transformatorima koji se koriste $\mathrm{u}$ energetici, posebice $\mathrm{u}$ elektroenergetici. Prema HJP-u, pridjev energetski odnosi se na energetiku ${ }^{4}$. Naziv učinske sklopke jednostavno je skraćen samo u sklopke.

U poglavlju Industrijska elektronika i automatsko upravljanje potpoglavlje je naslova »Sklopovi energetske elektronike « (str. 542), u kojem je učinjena hereditarna pogreška jer je u to doba »Rade Končar« već proizvodio opremu, ne samo za energetiku, već i za procesnu industriju i električnu vuču.

\section{Rječnici, Tehnički leksikon i Hrvatska enciklopedija}

Tablica 2. Naziv učinska elektronika u rječnicima, Tehničkom leksikonu i Hrvatskoj enciklopediji

\begin{tabular}{|c|c|c|}
\hline Publikacija & Natuknica & Prijevod \\
\hline $\begin{array}{l}\text { Elektrotehnički rječnik njemačko-hrvatski } \\
\text { (Muljević 1996: 492) }\end{array}$ & Leistungselektronik & učinska elektronika \\
\hline $\begin{array}{l}\text { Elektrotehnički rječnik hrvatsko-njemački } \\
\text { (Muljević, Horvatić 2000: 985) }\end{array}$ & učinska elektronika & Leistungselektronik \\
\hline \multirow[t]{2}{*}{$\begin{array}{l}\text { Elektrostrojarski rječnik - englesko-hrvat- } \\
\text { ski i hrvatsko-engleski (Vrban 2003: 48, 91) }\end{array}$} & power electronics & $\begin{array}{l}\text { energetska elektronika, } \\
\text { učinska elektronika }\end{array}$ \\
\hline & $\begin{array}{l}\text { energetska elektronika, } \\
\text { učinska elektronika }\end{array}$ & power electronics \\
\hline Tehnički leksikon (Jakobović 2007: 192) & $\begin{array}{l}\text { elektronika, učinska; } \\
\text { energetska elektronika }\end{array}$ & $\begin{array}{l}\text { power electronics, } \\
\text { Leistungselektronik } \\
\text { силовая электроника }\end{array}$ \\
\hline Hrvatska enciklopedija (Ravlić 2009: 141) & $\begin{array}{l}\text { učinska elektronika } \\
{\text { (energetska elektronika) }{ }^{(1)}}\end{array}$ & $\begin{array}{l}\text { nije dan naziv na } \\
\text { stranom jeziku }\end{array}$ \\
\hline
\end{tabular}

(1) Primijetimo da je naziv energetska elektronika naveden u zagradi.

4 Sinonim pridjeva energetski je pridjev energetički [6]. No pridjev energetički u inženjerskoj zajednici nije prihvaćen. 
Udžbenik Osnove učinske elektronike I i II (Kassakian-Schlecht-Verghese 2010, 2007)

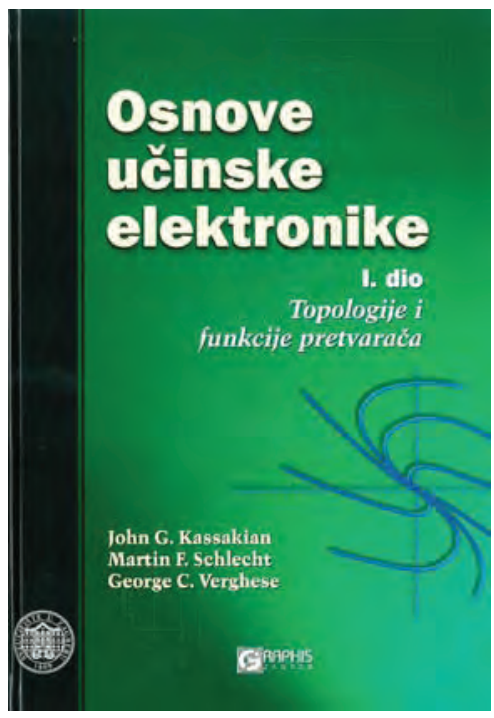

Slika 5. Naslovnica sveučilišnoga udžbenika iz učinske elektronike (prijevod udžbenika Principles of power electronics, Massachusetts Institute of Technology, 1991) (Kassakian-Schlecht-Verghese 2010, 2007)

Naziv učinska elektronika obuhvaća naziv energetska elektronika. Energetska elektronika je elektronika koja se primjenjuje samo u elektroenergetici, a učinska elektronika je elektronika koja se primjenjuje i u drugim područjima, primjerice u električnoj vuči, procesnoj industriji, u vojne svrhe, u kućanstvima i sl.

Svoju zadaću učinska elektronika ispunjava putem svojih uređaja (npr. pomoću učinskih elektroničkih pretvarača). Uređaji učinske elektronike prenose električnu energiju od ulaza do izlaza. Prijenos električne energije određuju ulazni i izlazni učin. Razlika između ulaznoga i izlaznoga učina jesu gubitci. Bitnost su uređaja mali gubitci električne energije, tj. velika učinkovitost. Pri prijenosu obično se mijenjaju obilježja električne energije (valni oblik struje, valni oblik napona, broj faza, frekvencija - uključujući frekvenciju nula) i upravlja tokom električne energije; tako se izvori električne energije prilagođuju trošilima. Dakle, ključna su obilježja uređaja učinske elektronike učinkovitost (Jakobović 2007) i ulazni učin.

\section{Kako i zašto je uveden naziv energetska elektronika?}

Pravopis hrvatskosrpskog jezika (Jonke, Stevanović 1960, 1967) posljedica je tzv. Novosadskoga dogovora. Novosadski je dogovor dokument od deset zaključaka o jeziku, koji su 1954. sastavili lingvisti i književnici iz Hrvatske, Srbije, Bosne i Hrvatske te Crne Gore (predstavnike Hrvatske pozvala je Matica srpska po svom izboru). Sasta- 
nak je organizirala Matica srpska u Novome Sadu radi donošenja zaključaka o potrebi jedinstvenoga pravopisa i ujednačivanja ponajprije hrvatskoga i srpskoga nazivlja za sve struke, a onda i jezičnoga ujednačivanja uopće. Šesti zaključak glasi:

»Pitanje izrade zajedničke terminologije takodje je problem koji zahteva neodložno rešenje. Potrebno je izraditi terminologiju za sve oblasti ekonomskog, naučnog i uopšte kulturnog života.« (ND 2019)

Nakon Novosadskoga dogovora naziv hrvatski jezik postupno nestaje s priručničkih naslova i iz javne uporabe, a zamjenjuje se nazivom hrvatskosrpski jezik ili pak hrvatski ili srpski jezik; izvan Hrvatske posve dominira naziv srpskohrvatski jezik. Nezadovoljstvo je kulminiralo donošenjem Deklaracije o nazivu i položaju hrvatskoga književnog jezika (sastavljena 9. ožujka 1967. u Matici hrvatskoj). (ND 2019)

Primjerice, u naslovu je školskoga izdanja pravopisa Matice hrvatske i Matice srpske (Jonke, Stevanović 1960) sintagma hrvatskosrpski jezik, u naslovu Tehničkog rječnika (Dabac 1969, 1970) riječ hrvatskosrpski, a u Pravopisnom priručniku (Anić, Silić 1987), objavljenom čak 1987. godine, sintagma hrvatski ili srpski jezik.

U takovim prilikama Institut »Nikola Tesla« iz Beograda organizirao je prvo (1973) i drugo (1975) »savetovanje« pod naslovom Energetska elektronika. Na završnoj sjednici drugoga savjetovanja formiran je Jugoslavenski koordinacioni odbor savjetovanja o energetskoj elektronici, koji se trebao brinuti o cikličkom kruženju savjetovanja od jedne do druge republike. Organizaciju trećega savjetovanja dobila je $\mathrm{Hr}$ vatska akademija znanosti i umjetnosti i SOUR ${ }^{5}$ »Rade Končar«. Akademik Petar Miljanić iz Srpske akademije nauka i umetnosti zatražio je od prof. Zlatka Plenkovića, direktora Instituta »Rade Končar«, da ne mijenja naziv savjetovanja. Treće savjetovanje održano je u Zagrebu 1978. godine. Peto savjetovanje održano je u Ljubljani 1984. godine, ali niti Slovenska akademija znanosti in umetnosti nije promijenila naziv energetska elektronika u močnostna elektronika.

Naziv energetska elektronika legaliziran je JUS-normom ${ }^{6}$ JUS N.A0.551 Energetska elektronika - Termini i definicije 1982., s time da je ta norma doslovni prijevod međunarodne norme IEC ${ }^{7}$ 50(551) iz 1982:

- energetska elektronika - dio elektronike koji se bavi energetskom tehnikom

- pretvorba (energetska) (elektronička) - promjena jedne ili više karakteristika nekog električkog energetskog sustava s pomoću elektroničkih

5 SOUR, složena organizacija udruženog rada

6 JUS, Jugoslavenski standard

7 IEC, International Electrotechnical Commission 
ventilskih komponenata, pri čemu je bitno da nema značajnog gubitka snage, karakteristike električkog sustava su, primjerice, napon, broj faza i frekvencija (uključujući frekvenciju nula).

Definicije sugeriraju da se radi o elektronici koja se primjenjuje u energetici. Čak i hrvatska norma HRN IEC 60050-551:1999 Energetska elektronika iz 1999. godine nije dovoljno jasna:

- energetska elektronika - područje elektronike koje se bavi pretvorbom ili sklapanjem električne energije, pri čemu se tom energijom upravlja ili ne upravlja.

- (elektronička) (energetska) pretvorba - promjena jedne ili više značajka kojega električnog energetskog sustava s pomoću elektroničkih ventilskih komponenata, pri čemu je bitno da nema većega gubitka snage. (Značajke su električnog sustava primjerice napon, broj faza i frekvencija, uključujući i frekvenciju nula).

\section{Naziv učinska elektronika na stranim jezicima}

Prema IEC rječniku nazivi su sljedeći:

engl. power electronics

franc. électronique de puissance

njem. Leistungselektronik

polj. energoelektronika

port. eletrónica de potencia

rus. силовая электроника

slo. močnostna elektronika

srp. energetska elektronika

španj. eletrónica de potencia

šved. kraftelektronik

tal. elettronica di potenza

Jedino je u poljskom i srpskom jeziku u nazivu riječ energija.

Mogući naziv snažna elektronika ili elektronika snage zbunjuje jer navodi na pogrešno pitanje koja je najmanja snaga uređaja učinske elektronike. Često sam čuo pitanje: može li se uređaj učinske elektronike staviti na stol? Najmanja snaga nije 
obilježje uređaja učinske elektronike, već učinkovitost (mali gubitci) bez obzira na snagu. U uređajima učinske elektronike nepoželjne su sve komponente koje unose gubitke, primjerice otpornici i tranzistori u linearnom načinu rada.

\section{Naziv skupine predmeta iz područja učinske elektronike na Tehničkom fakultetu / Elektrotehničkom fakultetu / Fakultetu elektrotehnike i računarstva u Zagrebu}

Tablica 3. Mijenjanje naziva skupine predmeta iz područja učinske elektronike od 1926. do 2019. (Petković 1996; Uremović 1969)

\begin{tabular}{|l|l|l|l|}
\hline $\begin{array}{l}\text { Početna šk. god. } \\
\text { nastavnog } \\
\text { programa }\end{array}$ & $\begin{array}{l}\text { Naslov skupine } \\
\text { predmeta }\end{array}$ & $\begin{array}{l}\text { Početna šk. god. } \\
\text { nastavnog programa }\end{array}$ & $\begin{array}{l}\text { Naziv skupine } \\
\text { predmeta }\end{array}$ \\
\hline $1919 / 20$. & nije se predavao & $1967 / 68$. & Usmjerivači \\
\hline $1926 / 27$. & nije se predavao & $1970 / 71$. ETF-3 & Usmjerivači \\
\hline $1936 / 37$. & nije se predavao & $1980 / 81$. ETF-4 & Energetska elektronika \\
\hline $1947 / 48$. & Električni usmjerivači & $1994 / 95$. FER-1 & Energetska elektronika \\
\hline $1951 / 52$. & Usmjerivači & $2005 / 06$. FER-2 & Učinska elektronika \\
\hline $1959 / 60$. & Usmjerivači & $2019 / 20$. FER-3 & Energetska elektronika \\
\hline
\end{tabular}

Tablica 3. pokazuje da se razvojem područja pretvorbe obilježja električne energije i upravljanja tokom električne energije, posebice električkih ventila, mijenjao naziv skupine predmeta. Vrijeme usmjerivača je vrijeme vladavine živinih ventila, najprije sa staklenom posudom, a zatim s čeličnom posudom. Već je 1970. godine postalo jasno da dolazi vladavina poluvodičkih ventila - silicijskih dioda i tiristora. No, sve do 1980. godine, do uvođenja nastavnog programa ETF-4, nije bilo prilike da se promijeni naziv Usmjerivači. Dogovorom predstojnika Zavoda za elektrostrojarstvo i automatizaciju (ZESA), prof. Radenka Wolfa i predstojnika Zavoda za elektroniku prof. Stanka Turka, odlučeno je da se u nastavnom programu ETF-4 promijeni naziv u Energetska elektronika i da matični zavod predmeta bude ZESA. U to doba forsiranja zajedničkoga nazivlja hrvatskog i srpskog jezika nije se niti pomišljalo da se uvede naziv učinska elektronika. Prva je prilika izmjene naziva 1994. godine, uvođenjem nastavnog programa FER-1, bila propuštena. Naziv učinska elektronika uveden je 2005. godine u nastavnom programu FER-2.

U jesen 2019. godine, demokratskim glasanjem, u nastavni program FER-3 vraćen je naziv energetska elektronika. Kada se znanstvene činjenice potvrđuju gla- 
sanjem, prestaje svaka znanost! Takvim demokratskim glasanjem planet Pluton izbačen je 2006. godine iz Sunčeva sustava pravih planeta. ${ }^{8}$

\section{Zaključak}

Nazivi energetska elektronika i učinska elektronika nisu sinonimi. Energetska je elektronika (engl. energy electronics) dio učinske elektronike koji se primjenjuje u elektroenergetici. Pridjev energetski označuje područje primjene, a pridjev učinski označuje bitnu intrinzičnu značajku (učinkovitost) elektroničkih sklopova za pretvorbu obilježja električne energije i upravljanje tokom električne energije.

Naziv učinska elektronika zadovoljava sva terminološka načela (Jakobović 2005): načelo jednoznačnosti (jedan naziv za jedan pojam i obratno), načelo razumljivosti (naziv podsjeća na pojam), načelo stručnosti (zadovoljavanje potreba struke), načelo jezične ispravnosti (usklađivanje s jezičnim normama), načelo informacijske pouzdanosti (izbjegavanje istoznačnica, sličnoznačnica i sl.) i načelo tvorbene plodnosti (mogućnosti tvorbe drugih vrsta riječi).

Povijesno i sadašnje vrludanje između naziva energetska elektronika i učinska elektronika pokazuje da jezični preskriptivizam može biti instrument moći, odnosno sredstvo održavanja dominacije pojedinih društvenih skupina i naroda nad drugima.

8 Pluton bi ponovno mogao postati planet, https://net.hr/danas/znanost/hoce-li-se-konacnoispraviti-nepravda-pluton-bi-ponovno-mogao-postati-planet/ (pristupljeno 5. I. 2020) 


\section{LITERATURA}

Anić, Vladimir (ur.) (2002). Hrvatski enciklopedijski rječnik. Zagreb: Novi Liber.

Anić, Vladimir, Silić, Josip (1987). Pravopisni priručnik hrvatskoga ili srpskoga jezika (2. izdanje). Zagreb: Sveučilišna naklada Liber-Školska knjiga.

Babić, Stjepan, Finka, Božidar, Moguš, Milan (1971). Hrvatski pravopis. Zagreb: Školska knjiga.

Babić, Stjepan, Finka, Božidar, Moguš, Milan (1996). Hrvatski pravopis (4. izdanje). Zagreb: Školska knjiga.

Belin, Boris (ur.) (1954). Informacije Rade Končar, br. 1 .

Boranić, Dragutin (1941). Pravopis hrvatskoga ili srpskoga jezika (8. izdanje). Zagreb: Nakladni zavod Banovine Hrvatske.

Boranić, Dragutin (1951). Pravopis hrvatskoga ili srpskoga jezika (10. izdanje). Zagreb: Školska knjiga.

Dabac, Vlatko (1969). Tehnički rječnik - 1. dio, Njemačko-hrvatskosrpski. Zagreb: Tehnička knjiga.

Dabac, Vlatko (1970). Tehnički rječnik - 2. dio, Hrvatskosrpsko-njemački. Zagreb: Tehnička knjiga.

Jakobović, Zvonimir (2005). Načela tvorbe hrvatskoga strukovnog nazivlja u ambalažnoj struci. Ambalaža, 10/2, str. 83-85.

Jakobović, Zvonimir (ur.) (2007). Tehnički leksikon A-Ž. Zagreb: Leksikografski zavod Miroslav Krleža.

Jonke, Ljudevit, Stevanović, Mihailo (ur.) (1960). Pravopis hrvatskosrpskog jezika (školsko izdanje). Zagreb-Novi Sad: Matica hrvatska-Matica srpska.

Jonke, Ljudevit, Stevanović, Mihailo (ur.) (1967). Pravopis hrvatskosrpskog jezika (školsko izdanje; 5. izdanje). Zagreb-Novi Sad: Matica hrvatska-Matica srpska.

Jurjević, Vladimir, Plavec, Viktor (ur.) (1980). Rade Končar - Tehnički priručnik (4. izdanje). Zagreb: SOUR Rade Končar-IRO Tehnička knjiga.

Kaiser, Dragutin (1956). Elektrotehnika - osnovi (4. izdanje). Zagreb: Tehnička knjiga, str. XXIV i XXV.

Kassakian, John G., Schlecht, Martin F., Verghese, George C. (2007). Osnove učinske elektronike, II. dio: Dinamika i upravljanje (preveo Zvonko Benčić). Zagreb: Graphis.

Kassakian, John G., Schlecht, Martin F., Verghese, George C. (2010). Osnove učinske elektronike, I. dio: Topologije i funkcije pretvarača (preveo Zvonko Benčić). Zagreb: Graphis.

Kutleša, Stipe (ur.) (2019). Filozofski leksikon. Zagreb: Leksikografski zavod Miroslav Krleža.

Lončar, Josip (1942). Osnovi elektrotehnike I Zagreb: Hrvatska državna tiskara u Zagrebu.

Lončar, Josip (1947). Osnovi elektrotehnike II Zagreb: Nakladni zavod hrvatske.

Lončar, Josip (1956). Osnovi elektrotehnike I (4. prošireno izdanje). Zagreb: Tehnička knjiga.

Lončar, Josip (1958). Osnovi elektrotehnike II (4. prošireno izdanje). Zagreb: Tehnička knjiga.

Lončar, Josip (1965). Električka mjerenja (4. izdanje). Zagreb: Tehnička knjiga.

Lopac, Vjera (2009). Leksikon fizike. Zagreb: Školska knjiga.

Muljević, Vladimir (1996). Elektrotehnički rječnik njemačko-hrvatski. Zagreb: Školska knjiga.

Muljević, Vladimir, Horvatić, Željko (2000). Elektrotehnički rječnik hrvatsko-njemački. Zagreb: Školska knjiga.

Musulin, Stjepan, Pavešić, Slavko (ur.) (1967-71). Rječnik hrvatskoga ili srpskoga jezika, XIX. Zagreb: Izdavački zavod Jugoslavenske akademije znanosti i umjetnosti.

Petković, Tomislav (ur.) (1996). Spomenica 1956.-1996., 40. obljetnica Fakulteta elektrotehnike i računarstva. Zagreb: Fakultet elektrotehnike i računarstva-Element.

Plohl, Miroslav (1927a). faka struja I, sv. I-VII (skripta). Zagreb: Udruženje slušača Tehničkog fakulteta.

Plohl, Miroslav (1927b). Faka struja II, sv. VII (skripta). Zagreb: Udruženje slušača Tehničkog fakulteta. 
Plohl, Miroslav (1928a). Faka struja I, Izmjenična jaka struja. Mjerenja (skripta). Zagreb: Udruženje slušača Tehničkog fakulteta.

Plohl, Miroslav (1928b). Faka struja II, sv. IX (skripta). Zagreb: Udruženje slušača Tehničkog fakulteta. Ravlić, Slaven (2009). Hrvatska enciklopedija, Tr-Ž. Zagreb: Leksikografski zavod Miroslav Krleža.

Šarić, Ljiljana, Wittschen, Wiebke (2008). Rječnik sinonima hrvatskoga jezika. Zagreb: Jesenski i Turk.

Šonje, Jure (ur.) (2000). Rječnik hrvatskog jezika. Zagreb: Leksikografski zavod Miroslav Krleža-Školska knjiga.

Šulek, Bogoslav (1874). Hrvatsko-njemačko-talijanski rječnik znanstvenog nazivlja. Zagreb: Narodna tiskara Dra. Ljudevita Gaja.

Uremović, Ivan (ur.) (1969). Spomenica 1919.-1969., 50 godina studija elektrotehnike u Hrvatskoj. Zagreb: Elektrotehnički fakultet Sveučilišta u Zagrebu-Tehnička knjiga.

Vrban, Marija (2003). Elektrostrojarski rječnik - englesko-hrvatski i hrvatsko-engleski. Zagreb: Graphis.

\section{MREŽNI IZVORI}

$H f P=$ Hrvatski jezični portal, http://hjp.znanje.hr/ (pristupljeno 4. I. 2020)

$N D=$ Novosadski dogovor, http://ihjj.hr/iz-povijesti/novosadski-dogovor/70/ (pristupljeno 24. XI. 2019)

Pluton bi ponovno mogao postati planet, https://net.hr/danas/znanost/hoce-li-se-konacno-ispraviti-nepravda-pluton-bi-ponovno-mogao-postati-planet/ (pristupljeno 5. I. 2020)

\section{USE OF THE TERM UČINSKA /ENERGETSKA ELEKRONIKA (POWER / ENERGY ELECTRONICS)}

\section{Zvonko Benčić}

University of Zagreb, Faculty of Electrical Engineering and Computing zvonko.bencic@fer.hr

ABSTRACT: The use of the noun učin (effect) and adjective ucinski (effective) in Croatian electrotechnical terminology is examined, covering the period from the publication of Sulek's Hrvatsko-njemačko-talijanski rječnik znanstvenog nazivlja [Croatian-German-Italian Dictionary of Scientific Terminology] in 1874 until today. It has been established that the term energetska elektronika (energy electronics) encompasses only part of meaning of ucinska elektronika (power electronics), that is, the part used in power engineering. The term ucinska elektronika is in line with the terminology used in most European languages (e. g. English, German, French, Russian, Italian, Slovenian) and satisfies all the principles of the formation of professional terminology.

Keywords: energy electronics; power electronics; effect; efficacy 